\title{
Experience of Legal Clinics in Matters of Legal Representation of Clients' Interests: Difference of Approaches
}

\author{
Trofimova M.S. \\ Yaroslav-the-Wise Novgorod State University, \\ Veliky Novgorod, Russia \\ rina23@inbox.ru
}

\begin{abstract}
The world educational experience proves that the legal clinic today is the most effective element of practiceoriented training in a law school. The possibilities of clinical education allow future lawyers to acquire practical skills even before graduation. The help of a professional mentor, in fact, "smooths out" the student's responsibility, allowing him to overcome the psychological barrier in front of real clients. The breadth of powers of a clinic student and the ability to fully immerse himself in the profession largely depends not only on national legislation on education, but also on regulations governing the position of a legal representative in civil or arbitration proceedings, as well as on the rules governing the principles of providing free legal help. According to the experience of all countries that have introduced clinical education, students advise citizens, prepare the necessary procedural documents for them. However, not all clinics allow students to perform the functions of a legal representative, which does not allow future lawyers to acquire the skills of participating in the process, developing a position on the case, analyzing evidence, etc. The reasons lie not only in the limited capabilities of legal clinics, but also in the professional monopolies on legal representation established in the procedural legislation. One of the prerequisites for ensuring economic security is the availability of high-quality drug provision for the population, ensured through the competent distribution of federal budget funds, effective targeting and budgeting in the health care sector of the Russian Federation, as well as a pharmacovigilance system capable of detecting and preventing side effects and other problems associated with medicines.
\end{abstract}

Keywords - legal education, free legal aid, legal clinic, legal representation, access to justice, practical skills

\section{INTRODUCTION}

There are many publications in the legal literature devoted to clinical legal education and the standards of legal clinics. Traditionally, authors discuss the value guidelines in the activities of clinics. Researchers and representatives of clinics raise the question: what is paramount in their activities, new educational technologies for teaching practical skills or helping real clients.
Most of the authors are inclined to believe that the clinic is a special form of the educational process, focused on the development of practical professional skills [1]. So, O.V. Isankova notes that "the protection of the rights of lowincome subjects is a secondary moment in relation to educational activities, while the protection of specific rights is a positive bonus of clinical education, but not an end in itself' [2]. Often, such positive effects of clinical training are highlighted, such as social adaptation and vocational guidance of students through communication with applicants by representatives of law enforcement agencies [3], the ability of legal clinics in the formation of expertise, including anticorruption [4], the formation of social competence, which determines the quality professional formation and development of the future bachelor [5].

In the foreign literature, tasks that are more complex are posed for the institutions of the university that implement clinical education programs.

Thus, Disability Human Rights Clinic founded at the University of Melbourne in 2015 implements projects of legislative and political reform, conducts strategic litigation. The clinic uses an innovative clinical legal education model to fill a curriculum gap and introduce a new generation of lawyers to the emerging field of human rights law with disabilities [6].

The University of Sheffield Law Clinic in the UK further links outcomes between student participation in pro bono projects and employment opportunities [7].

Thus, it is obvious that the possibilities and results of clinical legal education are very wide, especially taking into account the specifics of educational systems.

If we turn to domestic legislation, then the only, most complete mention of the activities of legal clinics is contained not in the regulations on higher education, but in the legislation on free legal aid.

Since 2011, legal clinics in Russia, which previously 
existed as structural units of universities, and performing part of the functions of an educational institution, have been included in the non-state system of free legal aid in the Russian Federation as an independent entity.

According to Article 22 of the Federal Law of 21.11.2011 No. 324-FZ "On Free Legal Aid in the Russian Federation" [8] legal clinics (student advisory bureaus, student law bureaus and others) and non-state centers of free legal aid are classified as participants in the non-state system of rendering free legal aid. The partners of clinics in the non-governmental system of assistance also include non-profit organizations, public receptions, non-governmental centers for free legal assistance of lawyers' associations, etc. However, in many regions of Russia it is clinics that are the most active and major "players" in the non-governmental system.

According to Article 23 of the Federal Law of 21.11.2011 No. 324-FZ "On Free Legal Aid in the Russian Federation", clinics are created for legal education of the population and the formation of legal aid skills among students in the legal profession.

However, since a legal clinic is a subject of a non-state system for providing free legal aid on the territory of the Russian Federation, there is an important goal of clinical training. This training is aimed at realization of the right of citizens to receive free legal aid established by the Constitution of the Russian Federation, ensuring the availability of mechanisms to protect the legitimate interests of citizens, and increasing the level of social protection, as well as ensuring their access to justice.

The implementation of these goals is possible only if the students of the clinic, who are non-professional lawyers, have the authority to represent the interests of low-income citizens in legal relations with the court, public authorities and institutions. However, not in all countries the procedural rules allow this.

\section{PROBLEM STATEMENT}

The analysis of legal acts on free legal aid allows us to formulate the following conclusion. Legal clinics can provide free legal assistance to real clients in the form of legal advice in oral and written forms, as well as drafting statements, complaints, petitions and other legal documents. In fact, the work of clinicians comes down to primary legal aid and the preparation of procedural documents for going to court. In accordance with Russian legislation on free legal aid, clinical students are deprived of the opportunity to represent the client's interests in courts and state and local authorities.

Representatives of Russian universities often note that the implementation of legal support for a client is one of the most demanded services, since clients of a legal clinic are, as a rule, elderly people, due to their age, they are not always healthy, and "going through the courts" is an absolutely impossible task for them [9].

The inability to carry out legal representation by students of a law school deprives the needy of the population to benefit from the help, albeit not of professional lawyers, but, nevertheless, of persons with some knowledge in the field of jurisprudence. In addition, it should be remembered that according to the rules of existing Russian clinics, consultations and any assistance to citizens are carried out only under the supervision of university teachers or practicing lawyers. Therefore, it is not true to talk about the poor quality of such services. An important factor is that citizens often need not legal, but rather psychological support from a person who has an idea of the stages and stages of the judicial procedure. Therefore, in typical, simple categories of disputes, the help of a law student is indispensable, especially considering the fees of lawyers in the commercial sector and representatives of the legal community.

But there is a more significant negative consequence of limiting the clinic's ability to exercise legal representation. If clinicians acquire only the skills of counseling and preparation of procedural documents, the main educational goal of clinical education, namely, the formation of complex practical professional skills of a lawyer, is not fully realized.

Participation in litigation, possession of public speaking skills, the ability to form a position on a case, analyze evidence, speak in court hearings are the most complex, complex practical skills that require preliminary training in the process of implementing clinical legal programs.

Despite the stated legislative restrictions, in practice, many law universities in Russia are getting out of this situation, their students carry out real judicial representation of clients' interests. This practice exists at Lomonosov Moscow State University, Ural State Law Academy, Yaroslav-the-Wise Novgorod State University, and many other educational institutions.

To use this opportunity even in the presence of the restrictions formulated in the legislation on free legal aid, the civil procedural legislation allows. So, in Article 49 of the Civil Procedure Code of the Russian Federation [10] it is indicated that representatives in the proceedings of the magistrate and in the district court may be capable persons, whose powers to conduct the case are duly formalized and confirmed.

Thus, the general requirements for a legal representative are his majority and legal capacity.

From October 1, 2019, only lawyers and other persons providing legal assistance who have a higher legal education or an academic degree in legal specialty can act as representatives in the courts of the subjects and the Supreme Court of the Russian Federation. Thus, the procedural legislation does not impose requirements on the professional education of a representative if the case is in the first instance in the proceedings of the magistrate or in the first instance or appeal in the district court.

However, these restrictions do not apply to cases of judicial representation by undergraduate students who successfully defend the rights and legitimate interests of the clinic's students in the appellate courts of the subjects, as well as in the cassation courts of general jurisdiction.

Despite the huge positive experience of Russian clinics in the implementation of judicial representation of clients' interests, it turns out that they provide such assistance in fact outside the scope of the legal clinic. This situation can cause distrust of citizens and, ultimately, affect the professional image of the legal clinic. 


\section{RESEARCH METHODS}

For a critical study of the national legislation on the activities of clinics, the comparative legal method and the method of system analysis were used as the main ones. In particular, the comparative legal method made it possible to identify global trends in determining the competence of clinical students and to recommend individual practices for implementation in domestic legislation on free legal aid. The method of comparative analysis made it possible to determine the prospects for the development of federal legislation on free legal aid in close connection with the norms of civil procedural legislation regulating the institution of judicial representation.

The study of the activities of Russian and foreign legal clinics made it possible to collect empirical data to formulate proposals for changing the current Russian legislation.

\section{FINDINGS}

The analysis of the work of legal clinics in Europe and the United States allows us to conclude that there is no uniform approach and established standards in admitting clinic students to legal representation.

The most dramatic experience is inherent in the American school. The students of the clinic with teachers-mentors carry out receptions on the basis of courts, the clinicians participate in the processes. At the same time, the categories of cases may not be the simplest ones. The experience of Syracuse University, located in Syracuse, New York, is indicative in this respect. The University offers interested students the opportunity to represent the interests of low-income individuals in pro bono bankruptcy cases under the supervision of a legal professor. On average, 40 to 60 student volunteers carry out this representation each year and represent about 20 bankruptcy clients. [11] It should be noted that bankruptcy legislation is traditionally one of the most complex in national legislation. The presence of such experience among American students indicates a complete mobilization of clinical programs for the acquisition of comprehensive practical skills.

In Europe, the situation is bipolar. For example, Poland has a unique history of aggressively deploying clinics nationwide, with an emphasis on clinical work focused on access to justice, the social mission of clinics and legal aid services that the state did not provide.

The strength of the Polish clinic system is that it is the only country in the Central and Eastern European region that provides a significant part of the national legal aid services through clinics, but the students themselves never appear in court [12].

In France, legal clinics are becoming more and more popular; their number is growing rapidly. Universities master individual programs for the implementation of clinical legal education [13]. However, French national law contains restrictions on the provision of free assistance to the population. Legal assistance by clinicians is provided in the form of oral consultations, but not related to judicial representation. Students of legal clinics in France provide free oral consultations to the low-income population and conduct information work for citizens [14].
In countries such as Peru, Argentina, South Africa, Australia, India, Italy, Korea, Malaysia, Haiti or Chile, clinical education programs are unique and can arise as a type of legal aid not only for individual, but also for group representation [15].

Richard J. Wilson, Professor at Cambridge University, in his comprehensive study "The global evolution of clinical legal education: more than a method" notes that today there is a common goal uniting clinics from all over the world - the implementation of universal access to justice by clinical students [16]. This topic of access to justice has strong roots in most legal systems. The notion that law schools can make a significant contribution to progress goes hand in hand with evolving legal aid legislation. This emphasis on access to justice puts the clinic directly in the debate about the role of the university in modern society.

\section{CONCLUSION}

Determining the emphasis on ensuring access to justice as the goal of implementing a clinical program puts the clinic on the agenda of the discussion about the role of the university in modern society. Is the primary goal of a university to prepare lawyers for a career and to implement educational standards? Alternatively, a legal clinic should fulfill its social mission by ensuring accessibility of justice to low-income segments of the population.

We believe that today legal clinics should go beyond just an innovative educational process that allows future lawyers to master the skills of working with citizens and documents. States should have reliable social partners in the professional legal environment, ready to take on part of the public functions to ensure the accessibility of the judicial system. Lawyers and other professional lawyers in the commercial sector provide free legal aid, usually with government and regional subsidies or grants. Such assistance, written into national legislation, is traditionally free for citizens, but funded for lawyers. Legal clinics have a pool of pro bono volunteers from among both teachers and students who are ready to provide proper judicial representation of low-income citizens at no cost.

A barrier to the realization of this most important goal of clinical education is the national procedural legislation containing professional qualifications for the work of a representative in court.

Diminishing the role of legal clinics in modern conditions is unjustified and impractical. A comparative analysis showed that in countries where students have the maximum opportunities and procedural powers in protecting the interests of the client in court, the practical effect of clinical legal education is more rapid and large-scale.

\section{References}

[1] L.S. Andreeva, V.V. Lyadov, "Legal clinic: concept, goals, perspectives" [Yuridicheskaya klinika: ponyatiye, tseli, perspektivy], Science and Education: Economy and Economics; Entrepreneurship; Law and Management, 2013, vol. 4(35), pp. 69-73.

[2] O.V. Isaenkova, "The Main Objective of the Legal Clinic: Protecting the Rights of the Poor or Skills of Students?" [Osnovnaia tsel' iuridichesko kliniki: zashchita prav maloimushchikh ili navyki studentov?], Bulletin of Civil Procedure, 2020, vol. 10(1), pp. 39-50. (In Russ.). DOI: 


\subsection{1/2226-0781-2020-10-1-39-50}

[3] S.L. Degtyarev, and P.G. Reshetnikov, "Interaction between a law school and prosecutors in organizing the work of a legal clinic" [Vzaimodeystviye yuridicheskogo vuza i organov prokuratury pri organizatsii raboty yuridicheskoy kliniki], Bulletin of Civil Procedure, 2020, vol. 10(1), pp. 51-58. (In Russ.). DOI: 10.24031/2226-0781-202010-1-51-58

[4] A.V. Chekmareva, "Searching for a New Model of Legal Education: Modern Approaches and Pedagogical Heritage of D.I. Meyer" [V poiskakh novoi modeli uridicheskogo obrazovaniia: sovremennye podkhody i pedagogicheskoe nasledie D.I. Meyera], Bulletin of Civil Procedure, 2020, vol. 10(1), pp. 81-90. (In Russ.). DOI: 10.24031/22260781-2020-10-1-81-90

[5] N.V. Kovchina, and S.A. Saprygina, "The social aspect of professional training of bachelor's degree students in the conditions of realization of the Federal State Educational Standards" [Sotsial'nyi aspekt professional'noi podgotovki budushchego bakalavra $\mathrm{v}$ usloviyakh realizatsii Federal'nykh gosudarstvennykh obrazovatel'nykh standartov], Pedagogical Journal, 2015, vol. 3, pp. 9-17. (In Russ.).

[6] Y. Maker, J. Offergeld, and A. Arstein-Kerslake, "Disability Human Rights Clinics as a model for teaching Participatory International Human Rights Lawyering", International Journal of Clinical Legal Education, 2018, vol 25(3), pp. 23-52. DOI: 10.19164/ijcle.v25i3.767

[7] S. Blandy, "Enhancing employability through student engagement in pro bono projects", International Journal of Clinical Legal Education. 2019, vol. 26 (1), pp. 7-45. DOI: http://dx.doi.org/10.19164/ijcle.v26i1.821

[8] Federal Law of 21.11.2011 No. 324-FZ "On Free Legal Aid in the Russian Federation”. (In Russ.). Retrieved from http://www.consultant.ru/document/cons_doc_LAW_121887

[9] S.S. Arsentieva, "Problems of development of legal clinics of universities", University Lawyer, 2018, vol. 9. (In Russ.). Retrieved from https://panor.ru/articles/problemy-razvitiya-yuridicheskikh-klinikvuzov/12043.html

[10] The Civil Procedure Code of the Russian Federation of November 14 2002 No. 138-FZ. (In Russ.). Retrieved from http://www.consultant.ru/document/cons_doc_LAW_39570

[11] G. Germain, "From Classroom to Courtroom: A Doctrinal Teach Supervises Pro Bono Bankruptcy Cases", Journal of Legal Education, 2013, vol. 62(4), pp. 612-620. Retrieved from https://jle.aals.org/home/vol62/iss4/8

[12] R.J. Wilson, Legal Aid and Clinical Legal Education in Europe and the USA: Are They Compatible?, in: Halvorsen Rønning O., Hammerslev O. (Eds.), Outsourcing Legal Aid in the Nordic Welfare States., Cham: Palgrave Macmillan, 2018. DOI: https://doi.org/10.1007/978-3-31946684-211

[13] X. Aurey, Law Clinics in France through the Prism of the Fundamental Rights Law Clinic, University of Caen Normandy, in A. Alemanno, L. Khadar (Eds.), Reinventing Legal Education: How Clinical Education Is Reforming the Teaching and Practice of Law in Europe, 2018. DOI: https://doi.org/10.1017/9781316678589.007

[14] O.Yu. Ilyina, and V.A. Ivanova, "Modern problems of the activities of legal clinics in France and Russia" [Sovremennyye problemy deyatel'nosti yuridicheskikh klinik vo Frantsii i Rossii], University Lawyer, 2018, vol. 9, pp. 24-27.

[15] R.A. Boswell, "Book Review of The Global Evolution of Clinical Legal Education: More Than a Method", Journal of Legal Education, 2018 , vol. 67(4), pp. 1081-1088. Retrieved from https://jle.aals.org/home/vol67/iss4/8

[16] R. Wilson, The Global Evolution of Clinical Legal Education: More than a Method, Cambridge: Cambridge University Press, 2017. DOI: $10.1017 / 978113919837$ 